\title{
Rational Economic Decision Making: The Relevance Among The Axioms of The Theory of Expected Utility
}

\author{
Rasyonel İktisadi Karar Alma:Beklenen Fayda Teorisi Aksiyomları \\ Arasındaki İlişki \\ Gelengül KOÇASLAN*
}

\begin{abstract}
The theory of expected utility is suggested by John Von Neumann and Oscar Morgenstern in 1944 and has had great currency until today because of its solid and consistent axiomatic structure. The theory explains economic behavior, decision making process, economic preferences and economic choices using the axioms. Although it still prevents its popularity; it has been seriously questioned by several behavioral and experimental research from 1950 because of the apparent difference between reality and the theory. The huge gap between economic behavior in real life situations and theory have been revealed and economists' view has been often criticisized for falling short of reality.
\end{abstract}

This paper provides a detailed description of all of the axioms of the theory of expected utility, reveals the relevance among them and presents a guidance for economic and interdisciplinary research.

Keywords: Expected utility theory, economic decision making, axioms, rationality.

\section{$\ddot{O} \mathbf{z}$}

Beklenen fayda teorisi John Von Neumann ve Oscar Morgenstern tarafindan 1944 yılında önerilmiş ve bugüne kadar sağlam ve tutarlı aksiyomatik yapısı nedeniyle büyük rağbet görmüş, geçerlilik kazanmıştır. Bu teori iktisadi davranışı, karar alma süreçlerini, iktisadi tercihleri ve seçimleri aksiyomları kullanarak açıklamaktadır. Her ne kadar popülaritesini korusa da; realite ve teori arasındaki bariz farklılık nedeniyle 1950 yllından sonra çeşitli davranışsal ve deneysel araştırmalarla ciddi biçimde sorgulanmıştır. Gerçek hayattaki iktisadi davranış ve teori arasındaki büyük boşluk açıklanmış ve iktisatçıların görüşü sıklıkla gerçeklikten uzak olmakla eleştirilmiştir.

$\mathrm{Bu}$ makale beklenen fayda teorisinin aksiyomlarının tamamının detaylı tanımını sağlamakta, aralarındaki ilişkiyi ortaya çıkarmakta ve iktisadi ve disiplinlerarası araştırmalar için bir kılavuz sunmaktadır.

Anahtar Kelimeler: Beklenen fayda teorisi, iktisadi karar alma, aksiyomlar, rasyonalite.

\section{Introduction}

The theory of expected utility is introduced to the literature by John Von Neumann who is a mathematician and Oscar Morgenstern who is an economist in 1944. The theory indeed arises as a finale of a process beginning with mathematician Luca Pacioli, physician, mathematician and astrologer Gerolamo Cardano ("the book on games of chance" published posthumously in 1663), mathematicians Blaise Pascal and Pierre de Fermat and proceeding with physicist, mathematician and astronomer Christiaan Huygens, mathematician Nikolaus Bernoulli, mathematician Pierre Reymon De Montmort, mathematician Gabriel Cramer and physicist, mathematician Daniel Bernoulli, mathematician Georges Louis Leclerc Comte de Buffon, mathematician Isaac Todhunter, mathematician and priest William Allen Whitworth, economist John Maynard Keynes and economist Carl Menger (Pacioli, 1494; Ore, 1953; Pascal and de Fermat, 1654; Huygens, 1656; De Montmort, 1713; Cramer, 1728; Bernoulli, 1738; Buffon, 1777; Todhunter, 1865; Whitworth, 1901; Keynes, 1921; Menger, 1934; Bassett, 1987; Dehling, 1997; Stigler, 1999; Székely and Richards, 2004; Pickover, 2009; Peters, 2011; Mukhopadhyay, 2012; Shlesinger, 2012; Garcia, 2013; Salov, 2014; CMU; Britannica).

\footnotetext{
* Doç. Dr., İstanbul Üniversitesi, İktisat Fakültesi, İngilizce İktisat Bölümü, kocaslan@istanbul.edu.tr
}

Koçaslan, G., (2019). Rational Economic Decision Making: The Relevance Among The Axioms of The Theory of Expected Utility, Gaziantep University Journal of Social Sciences, 18 (1), 535-548, Submission Date: 12-062018, Acceptance Date: 22-01-2019. 
The theory of expected utility examines economic decision making between risky prospects with single or multidimensional outcomes and has been the major paradigm in economic theory referring to economic behavior under risk since the Second World War and used prescriptively, predictively and descriptively in management science, finance and psychology respectively due to its convenience of mathematical applicability to any type of outcomes besides money (Schoemaker, 1982, p. 530, 531).

The theory of expected utility states that decision makers choose between risky prospects by comparing the expected utility values which are the weighted sums obtained by adding the utility values of outcomes multiplied by their respective probabilities (Mongin, 1998 , p. 171). In other words if an outcome $x$ is suggested with the probability value of $p_{x}$ and an outcome $y$ is suggested with the probability value of $p_{y}$; then the expected utility of an event $\mathrm{Q}$ is demonstrated as:

$$
\mathrm{EU}(\mathrm{Q})=\mathrm{x} \mathrm{p}_{\mathrm{x}}+\mathrm{y} \mathrm{p}_{\mathrm{y}}
$$

Similarly; the expected utility for two-outcome lottery $\mathrm{L}=(\mathrm{P}, \mathrm{A}, \mathrm{B})$ is:

$$
\mathrm{E}[\mathrm{U}(\mathrm{L})]=\mathrm{PU}(\mathrm{A})+(1-\mathrm{P}) \mathrm{U}(\mathrm{B})
$$

where the outcomes and their probabilities are denoted by A, B and $\mathrm{P},(1-\mathrm{P})$ respectively (Henderson and Quandt 1980, p. 54 ).

The utility function $\mathrm{U}: \mathrm{P} \rightarrow \mathrm{R}$ has an expected utility form and it is called von Neumann-Morgenstern $(\mathrm{vN}-\mathrm{M})$ expected utility function if there are numbers $\left(\mathrm{u}_{1}, \ldots, \mathrm{u}_{\mathrm{n}}\right)$ for each of the $N$ outcomes $\left(x_{1}, \ldots, x_{n}\right)$ such that for every $p \in P, U(p)=\sum_{i=1}^{n} p_{i} u_{i}$ (Mas-Colell et. al., 1995, p. 173; Muñoz-Garcia, 2017, p. 337; Dierks, 2005, p. 17; Herfert, 2006, p. 18; Levin, 2006, p. 6, 8, 29; Slantchev, 2005, p. 9). Mas-Colell et. al stated expected utility property as a cardinal property of utility functions defined on the space of lotteries and showed that the form of expected utility is preserved only by increasing linear transformations (Mas-Colell et. al. , 1995, p. 173). Von-Neumann-Morgenstern utility function "u" with objective probabilities is considered strictly increasing, concave, has at least two continuous derivatives (Kreps, 1990, p. 70, 84) and represents a consistent ranking of lotteries (Mobius, 2008, p. 5; Yanoff, 2012, p. 501).

A utility function is the reflection of individual preferences. Accordingly if $\mathrm{b} \preceq \mathrm{a}$ then it means that $u$ (b) $\leq u$ (a). In a few words; if a is preferred to b; this means that the utility attached to a is higher than the utility attached to $b$. Thus;

$\mathrm{u}: \mathrm{A} \rightarrow \mathfrak{R}(\mathrm{A}, \leq)$ if for all $\mathrm{a}, \mathrm{b} \in \mathrm{A} \rightarrow \mathrm{a} \leq \mathrm{b}$ if and only if $\mathrm{u}(\mathrm{a}) \leq \mathrm{u}$ (b) (Moschandreas, 2000, p. 110, 112; Alchian, 1953; Chakravarty, 2002, p. 32; Friedman and Savage, 1948; Mobius, 2008, p. 4).

The relationship between preferences and the utility function is basically viewed in three concepts;

1- if a consumer prefers $c_{1}$ to $c_{2}$ this means that the utility of $c_{1}$ is higher than the utility of $\mathrm{c}_{2}$ for the mentioned consumer

2- if a consumer prefers $c_{2}$ to $c_{1}$ this means that the utility of $c_{2}$ is higher than the utility of $\mathrm{c}_{1}$ for the mentioned consumer

3 - if a consumer is indifferent between two consumption bundles this means that the utility of $c_{1}$ is equal to the utility of $c_{2}$ for the mentioned consumer. 
If the preference relations are viewed as strong/strict, weak/nonstrict and indifference then (Shon, 2008, p. 1; Galaabataar and Karni, 2010; Schmeidler, 1971; Dubra, 2011; Karni, 2011, p. 2; Fishburn, 1986, p. 336):

-strong preference relation between risky prospects $\left(\mathrm{x}_{1}\right.$ and $\left.\mathrm{x}_{2}\right)$ is denoted by $\mathrm{x}_{1}>\mathrm{x}_{2}$ leads to $\mathrm{U}\left(\mathrm{x}_{1}\right)>\mathrm{U}\left(\mathrm{x}_{2}\right)$ where an option/alternative/event/prospect is evaluated more probable than the other.

-weak preference relation includes its symmetric complement “ " between risky prospects $\left(\mathrm{x}_{1}\right.$ and $\left.\mathrm{x}_{2}\right)$ is denoted by $\mathrm{x}_{1} \succsim \mathrm{x}_{2}$ leads to $\mathrm{U}\left(\mathrm{x}_{1}\right) \geq \mathrm{U}\left(\mathrm{x}_{2}\right)$ where an option/alternative/event/prospect is evaluated as at least as probable as the other and if $\mathrm{A} \approx \mathrm{B}$ then either $\mathrm{A}>\mathrm{B}$ or $\mathrm{A} \sim \mathrm{B}$.

-indifference preference relation refers to noncomparability between risky prospects $\left(\mathrm{x}_{1}\right.$ and $\left.\mathrm{x}_{2}\right)$ is denoted by $\mathrm{x}_{1} \sim \mathrm{x}_{2}$ leads to $\mathrm{U}\left(\mathrm{x}_{1}\right)=\mathrm{U}\left(\mathrm{x}_{2}\right)$ where options/alternatives/events/prospects are evaluated equally probable means that there is no significant difference sense between the options thus;

-if neither $\mathrm{A} \succsim \mathrm{B}$ nor $\mathrm{B} \approx \mathrm{A}$ then $\mathrm{A}$ and $\mathrm{B}$ are identified as noncomparable as suggested by Keynes (1929).

-if $\mathrm{A} \sim \mathrm{B}$ then neither $\mathrm{A}>\mathrm{B}$ nor $\mathrm{B}>\mathrm{A}$

$-\mathrm{A} \sim \mathrm{B}$ if $\mathrm{A} \approx \mathrm{B}$ and $\mathrm{B} \approx \mathrm{A}$,

$-\mathrm{A}>\mathrm{B}$ if $\mathrm{A} \approx \mathrm{B}$ and not $\mathrm{B} \approx \mathrm{A}$.

When the preference relation is denoted by " $>$ "; then characteristics of the preferences are summarized below (Fishburn, 1986, p. 336):

- asymmetry; if $\mathrm{A}>\mathrm{B}$ then not $\mathrm{B}>\mathrm{A}$

-completeness; $\mathrm{A} \approx \mathrm{B}$ or $\mathrm{B} \approx \mathrm{A}$

•asymmetry; If $\mathrm{A}>\mathrm{B}$ then not $\mathrm{B}>\mathrm{A}$

-nontriviality; $\mathrm{S}>\varnothing$

•nonnegativity; $\mathrm{A} \approx \varnothing$

-monotonicity; If $\mathrm{A} \supseteq \mathrm{B}$ then $\mathrm{A} \approx \mathrm{B}$

-inclusion monotonicity; If $\mathrm{A} \supseteq \mathrm{B}, \mathrm{B}>\mathrm{C}$ or $\mathrm{A}>\mathrm{B}, \mathrm{B} \supseteq \mathrm{C}$ then $\mathrm{A}>\mathrm{C}$

-transitivity; If $\mathrm{A}>\mathrm{B}$ and $\mathrm{B}>\mathrm{C}$ then $\mathrm{A}>\mathrm{C}$

-additivity; If $\mathrm{A} \cap \mathrm{C}=\varnothing=\mathrm{B} \cap \mathrm{C}$ then $\mathrm{A}>\mathrm{B} \Leftrightarrow \mathrm{A} \mathrm{AUC}>\mathrm{BUC}$

-complementarity; If $\mathrm{A}>\mathrm{B}$ then not $\mathrm{A}^{\mathrm{c}}>\mathrm{B}^{\mathrm{c}}$

$* A$ and $B$ are events, $\varnothing$ and $S$ are empty and universal events respectively and $\varnothing \subseteq A \subseteq S$.

Unsurprisingly the assumptions of the theory of expected utility, the mathematical structure behind and the theory itself are harmonized with each other. For this reason the utility function is usually mentioned as "von Neumann- Morgenstern utility function" in some of the source books.

If the decision problem is assumed to consist of the set of outcomes, then the preference relation is expected to satisfy the axioms below to be consistent with the theory of expected utility and to be labeled as rational behavior/decision: 
-Invariance

-Completeness (Complete-Ordering)

-Transitivity

-Continuity

-Independence

-Complete-Ordering

-Unequal-Probability

-Archimedean

-Monotonicity

-Substitution (Independence of Irrelevant Alternatives)

This paper is organized as follows. In section 2 the axioms of the theory of expected utility are explained in detail. Section 3 presents the relevance among them and section 4 concludes considering the concept of economic rationality.

\section{Axioms Of The Theory Of Expected Utility}

The axioms of the theory of expected utility are explained in detail in this section.

\section{Invariance}

According to invariance axiom preference between alternatives is independent of how they are framed. In other words; a rational decision maker's preferences are not affected by the framing of the prospects.

On the other hand there are revealed situations where framing matters. It is prooved that framing of a choice problem affects preferences (Tversky and Kahneman, 1981; Kahneman and Tversky, 1984; Tversky and Kahneman, 1986; Kahneman, 2003).

\section{Completeness}

Completeness axiom is also known as "the complete-ordering" axiom. If an individual can make a comparison between alternatives when he/she is asked to make a choice, his/her preferences are said to be complete (Board, 2009, p. 2). According to the completeness any two outcomes, goods or consumption bundles can be ranked or judged by the consumer as $\mathrm{c}_{1} \approx \mathrm{c}_{2}, \mathrm{c}_{1} \preccurlyeq \mathrm{c}_{2}, \mathrm{c}_{1} \sim \mathrm{c}_{2}$ or $\left(\mathrm{x}_{1}, \mathrm{x}_{2}\right)>\left(\mathrm{y}_{1}, \mathrm{y}_{2}\right),\left(\mathrm{y}_{1}, \mathrm{y}_{2}\right)>\left(\mathrm{x}_{1}, \mathrm{x}_{2}\right),\left(\mathrm{x}_{1}, \mathrm{x}_{2}\right) \sim\left(\mathrm{y}_{1}, \mathrm{y}_{2}\right)$ ensuring that all choices can be ordered in a single chain without gaps pairwising the comparability of all prospects (Shon, 2008, p. 2; Dean, 2009, p. 6; Abdellaoui, 2002, p.3).

On the other hand; completeness is diffucult to be satisfied if both alternatives are considered good along different dimensions, if they are complicated or very emotional and if there is an addiction to a substance (Dean, 2009, p. 7).

\section{Transitivity}

Outcomes, goods, prospects or consumption bundles can be ordered in a single chain without cycles and can be ranked consistently by the rational consumer according to the transitivity axiom (Abdellaoui, 2002, p. 3). Internally consistent preferences are stated as transitive (Board, 2009, p. 2). Transitivity axiom also implies that the indifference curves don't intersect.

If $\mathrm{a}, \mathrm{b}, \mathrm{c}$ are outcomes, goods or consumption bundles; if $\mathrm{a}$ is preferred to $\mathrm{b}$ and $\mathrm{b}$ is preferred to $\mathrm{c}$ then $\mathrm{a}$ is preferred to $\mathrm{c}$ : 


$$
\mathrm{a} \geq \mathrm{b}, \quad \mathrm{b} \geq \mathrm{c} \quad \Rightarrow \quad \mathrm{a} \geq \mathrm{c}
$$

On the other hand; preferences between similar alternatives leads to failure of transitivity (Dean, 2009, p. 8). Violations of transitivity axiom is revealed by several research (Tversky, 1969; Loomes et. al. , 1991; Tversky, 2004; Birnbaum and Schmidt, 2008; Day and Loomes, 2010).

\section{Continuity}

Continuity axiom is sometimes called as the Archimedean axiom (Föllmer et. al. , 2016, p. 58, Slantchev, 2005, p. 8; Levin, 2006, p. 5). According to the continuity axiom if $\mathrm{A}>\mathrm{B}>\mathrm{C}$ then there is some probability $\mathrm{P}(0<\mathrm{P}<1)$ such that the consumer is indifferent between outcome B with certainty and and a lottery that suggests the outcome A with the probability value of $\mathrm{P}$ and the outcome $\mathrm{C}$ with the probability value of 1-P (Henderson and Quandt, 1980, p. 53):

$$
\text { if } \mathrm{A}>\mathrm{B}>\mathrm{C} \Rightarrow \mathrm{B} \sim(\mathrm{P}, \mathrm{A}, \mathrm{C})
$$

When the preference relation between lotteries $p, p^{\prime}$ and $p^{\prime \prime}$ is $p \geq p^{\prime} \geq p^{\prime \prime}$, then $\alpha p+(1$ $-\alpha) \mathrm{p}^{\prime \prime} \sim \mathrm{p}^{\prime}$ means that if $\mathrm{p}$ is preferred to $\mathrm{p}^{\prime}$, a lottery close to $\mathrm{p}$ will still be preferred to $\mathrm{p}^{\prime}$ (Levin, 2006, p. 5).

Satisfaction of continuity axiom that is accompanied by a continuous utility function, refers to infinity of choices (Mobius, 2008, p. 5; Board, 2009, p. 9):

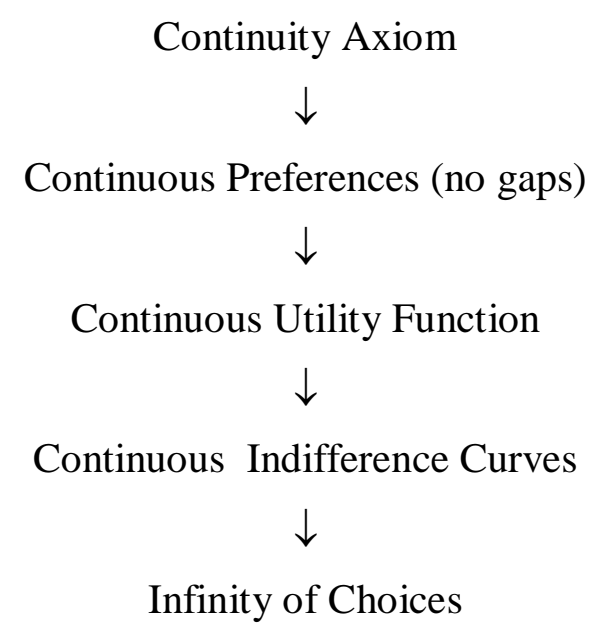

On the other hand if a consumer is asked to make a choice between two consumption bundles with the goods $x_{1}$ and $x_{2}$; he/she prefers the bundle with the most $x_{1}$ and if the two bundles have the same $x_{1}$ then he/she prefers the bundle with the most $x_{2}$ which is consistent with the lexicographic preferences but contradicts with the continuity axiom (Board, 2009, p. $5,6)$.

\section{Archimedean}

According to Archimedean axiom for the outcomes peserving the preference relation a $<\mathrm{b}<\mathrm{c}$ there is a lottery $\mathrm{L}=\{(\mathrm{a}, \alpha),(\mathrm{c}, 1-\alpha)\}$ such that the individual is indifferent between the lottery L and the outcome b (Mobius, 2008, p. 6):

$\mathrm{a}<\mathrm{b}<\mathrm{c} ; \mathrm{L}=\{(\mathrm{a}, \alpha),(\mathrm{c}, 1-\alpha)\} \leftrightarrow \mathrm{L} \sim \mathrm{b}$

Archimedean axiom is related to infinite sensitivity of preference judgment (Abdellaoui, 2002, p.3):

$$
(\mathrm{P}>\mathrm{Q}>\mathrm{R}) \rightarrow \alpha \mathrm{P}+(1-\alpha) \mathrm{R}>\mathrm{Q}>\beta \mathrm{P}+(1-\beta) \mathrm{R} \text { for some } \alpha, \beta \in] 0,1[
$$




\section{Monotonicity}

The monotonicity axiom verifies that higher utility is preferred and refers to the basic principle of economics "more is better than less". According to monotonicity axiom more pleasure is derived by consuming more commodities (Shon, 2008, p. 2):

if $\mathrm{c}_{1}$ and $\mathrm{c}_{2}$ are consumption bundles and

if $\mathrm{c}_{1}$ contains more of each commodity than $\mathrm{c}_{2}$ does $\rightarrow \mathrm{c}_{1}>\mathrm{c}_{2}$

then $c_{1}$ is preferred to $c_{2} \rightarrow c_{1}>c_{2}$.

Monotonocity reveals the relevance between lottery preference and probability values (Mobius 2008:6):

if lottery $\mathrm{L}_{1}$ is preferred to lottery $\mathrm{L}_{2}$ and if $\alpha>\beta$ then $\left\{\left(\mathrm{L}_{1}, \alpha\right) ;\left(\mathrm{L}_{2} ; 1-\alpha\right)\right\}$ is preferred to $\left\{\left(\mathrm{L}_{1}, \beta\right),\left(\mathrm{L}_{2}, 1-\beta\right)\right\}$.

By the ultimate aim of utility maximization and by monotonicity axiom a homoeconomicus prefers to consume more and if there were no budget limits or diminishing marginal utility; he/she would prefer to continue consuming. As the utility is fixed along an indifference curve and an indifference curve is the representation of different consumption bundle combinations with the same total utility; monotonicity axiom clarifies why indifference curves don't intersect (Board, 2009, p. 7, 9, 13):

-convex indifference curves means that marginal rate of substitution is positive and is decreasing along the indifference curve

-if $x \geqslant y$ then $t x+(1-t) y \geqslant y$ for all $t \in[0,1]$ and similarly $u(t x+(1-t) y) \geq u(y)$ for all $\mathrm{t} \in[0,1]$ then preferences are convex

- indifference between $x$ and $y$ means preference of the average $t x+(1-t) y$ to either $x$ or y leads to preference of averages to extremes

-one indifference curve must always lie to the northeast of the other

-an individual will always spend his/her budget

-monotonicity and thus convexity are essential to analyze utility maximization and to solve first order conditions and inflexion points

-if $u(t x+(1-t) y) \geq u(y)$ for all $t \in[0,1]$ then the utility function is quasi-concave. The quasi-concave shape of the utility function means convex preferences (Dean, 2009, p. 22).

On the other hand; indifference curves don't intersect because of the transtiviy axiom as well even if the monotonicity axiom is never assumed.

\section{Substitution}

Substitution axiom is also known as the "independence of irrelevant alternatives". According to substitution axiom if lottery $\mathrm{L}_{1}$ is preferred to lottery $\mathrm{L}_{2}$ then any mixture of these lotteries with any other lottery $\mathrm{L}_{3}$ preserves the same preference order (Mobius, 2008, p. 6):

$$
\left\{\left(\mathrm{L}_{1}, \alpha\right),\left(\mathrm{L}_{3}, 1-\alpha\right)\right\} \geq\left\{\left(\mathrm{L}_{2}, \alpha\right),\left(\mathrm{L}_{3}, 1-\alpha\right)\right\}
$$

\section{Compound Lottery}

A lottery $\mathrm{L}$ which is demonstrated as $\mathrm{L}=\left\{\left(\mathrm{L}_{1}, \mathrm{p}_{1}\right),\left(\mathrm{L}_{2}, 1-\mathrm{p}_{1}\right)\right\}$ or $\mathrm{L}=\left(\mathrm{L}_{1}, \mathrm{~L}_{1}, \mathrm{p}_{1}\right)$ called as a compound lottersy as it includes another lottery or lotteries in it. 
If $\mathrm{L}=\left\{\left(\mathrm{L}_{1}, \mathrm{p}_{1}\right),\left(\mathrm{L}_{2}, 1-\mathrm{p}_{1}\right)\right\}$ or $\mathrm{L}=\left(\mathrm{L}_{1}, \mathrm{~L}_{2}, \mathrm{p}_{1}\right)$ is a given compound lottery. The lottery $\mathrm{L}$ suggests the lottery $\mathrm{L}_{1}$ with the probability value of $\mathrm{p}_{1}$ and lottery $\mathrm{L}_{2}$ with the probability value of $1-p_{1}$.

It is important that each compound lottery is equivalent to a simple lottery with the same probability distribution over final outcomes (Mobius, 2008, p. 6) consistent with the basic inference of the theory ignoring the difference between the valuation of monetary gains and losses and only focuses on the final asset position.

\section{Reflexivity}

For any consumption bundles, goods or prospects; one is at least as good as itself. According to the reflexivity axiom, if $\mathrm{c}_{\mathrm{i}}$ is a consumption bundle then:

$$
\mathrm{c}_{\mathrm{i}} \succsim \mathrm{c}_{\mathrm{i}}
$$

Independence

According to independence axiom a rational decision maker's preference shouldn't depend on the "common consequence" $\mathrm{R}$; when he/she is asked to make a choice between $\alpha \mathrm{P}+(1-\alpha) \mathrm{R}$ and $\alpha \mathrm{Q}+(1-\alpha) \mathrm{R}$ (Abdellaoui, 2002, p. 3):

$$
(\mathrm{P}>\mathrm{Q}, \alpha \in[0,1]) \rightarrow(\alpha \mathrm{P}+(1-\alpha) \mathrm{R}>\alpha \mathrm{Q}+(1-\alpha) \mathrm{R}
$$

The independence axiom is mentioned as the key axiom and the heart of the expected utility theory. According to the independence axiom individuals ignore the common parts when they are making a choice:

if $\mathrm{a}, \mathrm{b}, \mathrm{c}$ are different outcomes and the preference between $\mathrm{a}$ and $\mathrm{b}$ is:

$$
\mathrm{a}>\mathrm{b}
$$

then when the individual is asked to make a choice between these two outcomes presented with the outcome $\mathrm{c}$ in common; the preference order preserves the previous preference relation as:

$$
\mathrm{a}+\mathrm{c}>\mathrm{b}+\mathrm{c} \text {. }
$$

In other demonstration where probability values are included:

if an individual is asked to make a choice between $\alpha x+(1-\alpha) y$ and $\alpha z+(1-\alpha) y$, the common part $(1-\alpha) \mathrm{y}$ is ignored and the individual considers $\alpha \mathrm{x}$ and $\alpha \mathrm{z}$. Therefore the independence axiom is usually confused with the substitution axiom.

The independence axiom is also equivalent to having indifference curves that are parallel straight lines leading to preferences representable by a vN-M expected utility function (Levin, 2006, p. 9, 29):

- if $\mathrm{p} \sim \mathrm{p}^{\prime}$, then by independence $\mathrm{p} \sim \alpha \mathrm{p}+(1-\alpha) \mathrm{p}^{\prime} \sim \mathrm{p}^{\prime}$, means that indifference curves must be straight lines.

•if indifference curves are not parallel, then $\mathrm{p}^{\prime} \sim \mathrm{p}$ and but $1 / 2 \mathrm{p}^{\prime}+1 / 2 \mathrm{p}^{\prime \prime}>1 / 2 \mathrm{p}+1 / 2 \mathrm{p}^{\prime \prime}$.

On the other hand; there is a huge literature reveals the systematic violations of the independence axiom (Kahneman and Tversky, 1979; Holt, 1986; Machina, 1987; Loomes, 1991; Carlin, 1992; Day and Loomes, 2010).

\section{Unequal-Probability Axiom}

According to unequal-probability axiom if the consumer prefers the outcome $\mathrm{A}$ to the outcome $B$ and $L_{1}$ and $L_{2}$ are the lotteries that suggest the outcome $A$ with the probability 
value of $\mathrm{P}_{1}$ and the outcome $\mathrm{B}$ with the probability value of 1- $\mathrm{P}_{1}$ and the outcome $\mathrm{A}$ with the probability value of $\mathrm{P}_{2}$ and the outcome $\mathrm{B}$ with the probability value of $1-\mathrm{P}_{2}$ respectively then $L_{2}$ is preferred to lottery $L_{1}$ if and only if the probability value of $P_{2}$ is higher than the probability value of $\mathrm{P}_{1}$.

If $\mathrm{A}>\mathrm{B}$ and $\mathrm{L}_{1}=\left(\mathrm{P}_{1}, \mathrm{~A}, \mathrm{~B}\right)$ and $\mathrm{L}_{2}=\left(\mathrm{P}_{2}, \mathrm{~A}, \mathrm{~B}\right)$ then $\mathrm{L}_{2}>\mathrm{L}_{1}$ if and only if $\mathrm{P}_{2}>\mathrm{P}_{1}$ (Henderson and Quandt, 1980, p. 53).

\section{The Relevance Among The Axioms}

Von Neumann and Morgenstern (1947) suggested that a complete and transitive preference relation $\geq$ on $\mathrm{P}$ satisfies continuity and independence if and only if it admits a expected utility representation $\mathrm{U}: \mathrm{P} \rightarrow \mathrm{R}$ (Levin, 2006, p. 6, 8, 29). It is also stated that the axioms; completeness, transitivity, independence and Archimedean are necessary and sufficient for a real-valued utility function that is linear in the probabilities, unique up to a positive affine transformation and represensts a ranking of exogenously determined preferences to exist (Abdellaoui, 2002, p. 3, 4).

Von Neumann-Morgenstern utility function is unique up to positive linear transformations where $\mathrm{U}^{*}(\mathrm{x})$ preserves the same preferences with $\mathrm{U}(\mathrm{x})$ as long as $\mathrm{U}^{*}(\mathrm{x})=$ $\mathrm{aU}(\mathrm{x})+\mathrm{b}$ for $\mathrm{a}>0$ and $\mathrm{b}$ (Schoemaker, 1982, p. 531). Any strictly increasing transform of a utility function represents the same preferences with the previous one as a monotonic transformation of a utility function is another strictly increasing utility function thus addition, subtraction, multiplication or taking its logarithm preserves the original utility function (Dean, 2009, p. 20).

Here there are two terms need to be expressed "non-decreasing" and "strictly increasing" regarding to the utility function (Shon, 2008, p. 2):

-a utility function $\mathrm{U}$ is non-decreasing if $\mathrm{c}_{1} \geq \mathrm{c}_{2}$ implies $\mathrm{U}\left(\mathrm{c}_{1}\right) \geq \mathrm{U}\left(\mathrm{c}_{2}\right)$ and vice-versa for a non- increasing utility function

-a utility function $\mathrm{U}$ is strictly increasing if $\mathrm{c}_{1}>\mathrm{c}_{2}$ implies $\mathrm{U}\left(\mathrm{c}_{1}\right)>\mathrm{U}\left(\mathrm{c}_{2}\right)$ and vice-versa for a strictly decreasing utility function.

In the light of this information, it is concluded that preferences are monotone if and only if the utility function $U$ is non-decreasing and they are strictly monotone if and only if the utility function $U$ is strictly increasing.

The connection between continuity and completeness axioms is proved by representing that a nontrivial preorder on a connected topological space is continuous only if it is complete (Schmeidler, 1971, Karni, 2007, Karni, 2011, p. 2). On the other hand a nontrivial preorder on the set of lotteries satisfying the independence and Archimedean axioms can be incomplete although it is stated if a preorder on the set of lotteries which are probability distributions on a finite set of prizes is nontrivial and satisfies the independence axiom then the satisfaction of any two of Archimedean, continuity and completeness imply the third (Dubra, 2011, Galaabataar and Karni, 2010, Karni, 2011, p. 2).

If a decision problem consisting of a finite set of outcomes a preference relation on these outcomes is expected to satisfy completeness and transitivity as two elementary axioms implying individual preferences without gaps and cycles (Mobius, 2008, p. 4). Completeness is applicable by transitivity and a preference relation is expected to satisfy completeness and transitivity axioms at least (Shon, 2008, p. 2). As long as completeness and transitivity are satisfied all equivalent outcomes can be ordered in a strictly increasing chain (Mobius, 2008, p. 4). Once preferences satisfy completeness and transitivity axioms, first order stochastic dominance is implied by independence axiom (Abdellaoui, 2002, p. 3). 
If $\geq$ is a preference relation satisfies completeness, transitivity and continuity then the indifference curves are parallel straight lines satisfying the independence axiom as well and is representable by a linear or affine utility function in probabilities (Ordoñez, 2007, p. 3):

$$
\text { if } \mathrm{p}<\mathrm{q} \text {, by monotonicity } \mathrm{U}(\mathrm{p})<\mathrm{U}(\mathrm{q})
$$

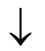

$$
\text { for all } \alpha \in[0,1] \text { and all } r \in L, \alpha U(p)+(1-\alpha) U(r)<\alpha U(q)+(1-\alpha) U(r) \text { then }
$$$$
\text { independence axiom is satisfied }
$$

indifference curves are parallel straight lines.

Linearity in the probabilities is that $U\left(\alpha p+(1-\alpha) p^{\prime}\right)=\alpha U(p)+(1-\alpha) U\left(p^{\prime}\right)$ holds for every $p, p^{\prime}$ and $\alpha$ means that $U$ must be constant on the line connecting $p$ and $p^{\prime}$, then it must have an expected utility form leading to linear indifference curves (Levin, 2006, p. 6, 8, 29):

the linearity of expected utility

parallel straight lines indifference curves

the preferences are representable by an expected utility function

The representativeness of the axioms of the theory of expected by a linear utility function means that a nonlinear utility function is incompatible with the axioms of the theory. Although it is sometimes mentioned that the satisfaction of completeness, transitivity and continuity or completeness and transitivity or completeness, transitivity, independence and Archimedean or substitution, Archimedean and monotonicity is sufficient for preferences to be representable by von Neumann-Morgenstern expected utility function (Board, 2009, p. 8; Abdellaoui, 2002, p. 4; Levin, 2006, p. 5); all of the assumptions are needed to be satisfied in order to determine and model the original preference ordering of a rational decision maker compatible with the theoretical structure of the theory of expected utility

\section{Conclusion}

The theory of expected utility has an extremely consistent structure in itself. All of the axioms are deliberated and designed in a manner to confirm each other. The theme of "economic rationality" is substantiated by this perfectly working mechanism and the concept of economic human; "homoeconomicus" was borned. The homoeconomicus is portrayed as a rational, unemotional, ultimate utility maximizer equipped with perfect and correct information.

However rationality is found as disorienting due to its theoretical and daily life perception. The conflict arises when a behavior satisfying axioms and thus labeled as "rational" comprehended "irrational" (or vice versa) in individual's mind. Rational means logical and reasoned. Thus the controversy arises when an economic activity seeming reasonable and logical in daily life isn't labeled as rational "theoretically" unless it satisfies the axioms of the theory of expected utility. Theoretically an economic behavior or a decision is called as "rational" as long as the axioms of the theory -which are explained in detail 
throughout the paper- of the expected utility theory are satisfied. Likewise decision or behavior doesn't meet the axioms is called as "irrational" theoretically. How much or which of the axioms are needed to be satisfied in order to call a decision or a behavior as rational (or irrational) is an other questionable issue.

Although theory's admirable mathematical structure is sometimes attributed to the mathematicians' and physicists' involvement and to the endeavor to substantiate economics as a science; the theory of expected utility is still the basic reference explaininig consumer behavior under risk and uncertainy beyond argument. At the same time the theoretical view needs to be improved in a way to meet the needs, to serve the solution of economic problems in everyday life rather than merely meeting the mathematical axioms. Thereby the gap between real life situatons and theory decreases and as a basic criticism directed, falling short of reality can be overcomed.

\section{References}

Abdellaoui, M. (2002). Economic rationality under uncertainty. GRID-CNRS, ENS de Cachan.

Alchian, A. A. (1953). The meaning of utility measurement. The American Economic Review, 43(1), 26-50.

Bassett, G.W. Jr. (1987). The St. Petersburg Paradox and bounded utility. History of Political Economy, 19(4), 517-523.

Bernoulli, D. (1954). Exposition of a New Theory on the Measurement of Risk.

Econometrica, 22(1): 23 - 36. (Specimen Theoriae Novae de Mensura Sortis. Commentarii Academiae Sceintiarum Imperialis Petropolitanae, Tomus V, 1738, 175 - 192.)

Birnbaum, M. H. , \& Schmidt, U. (2008). An experimental investigation of violations of transitivity in choice under uncertainty. Kiel Working Paper No. 1396.

Board, S. (2009). Preferences and utility. Resource document. UCLA. http://www.econ.ucla.edu/sboard/teaching/econ11_09/econ11_09_lecture2.pdf. Accessed 28 June 2017.

Britannica. https://www.britannica.com/topic/The-Book-on-Games-of-Chance. Accessed 28 June 2017.

Buffon, G. L. L. Comte de. ( 1777)ESSAIS d'Arithm'etique morale. In: Histoire Naturelle. Suppl'ement Tome Quatri'eme. Paris: De l'Imprimerie Royale, 46 - 124.

Carlin, P. S. (1992). Violations of the reduction and independence axioms in Allais-Type and common-ratio effect experiments. Journal of Economic Behavior \& Organization, 19(2), 213-235.

Carnegie Mellon University. http://www.link.cs.cmu.edu/15859s11/notes/Mcfadyen_review.pdf. Accessed 28 June 2017.

Chakravarty S. R. (2002). Microeconomics. New Delhi: Allied Publishers.

Day, B., \& Loomes, G. (2010). Conflicting violations of transitivity and where they may lead us. Theory and Decision, 68, 233-242. 
Dean, M. (2009). Consumer theory. Resource document. Columbia University. http://www.columbia.edu/ md3405/IM_CT.pdf. Accessed 28 June 2017.

Dehling, H. G. (1997). Daniel Bernoulli and the St. Petersburg Paradox. Vierde Serie Deel, 15(3), 223-227.

de Montmort, P. R. (1713). Essay d'Analyse sur les Jeux de Hazard. Paris:Jacque Quillau.

Dierks, L. H. (2005). Trust as a determinant of consumer behaviour under uncertainty: an empirical analysis of consumers' reactions to a random external shock in Europe. Kiel:Cuvillier Verlag.

Dubra, J. (2011). Continuity and completeness under risk. Mathematical Social Sciences, 61, 80-81.

Fishburn, P. C. (1986). The axioms of subjective probability. Statitstical Science, 1(3), 335345.

Föllmer, H., \& Schied, A. (2011). Stochastic finance: an introduction in discrete time. Berlin: de Gruyter.

Friedman, M. ,\& Savage, L. J. (1948). The utility analysis of choices involving risk. The Journal of Political Economy, 56 (4), 279-304.

Galaabataar, T., \& Karni, E. (2010). Objective and subjective expected utility with incomplete preferences. Economics Working Paper from the archive of The Johns Hopkins University.

Garcia, J. A. (2013). A bit about the St. Petersburg Paradox. http://www.math.tamu.edu/ david.larson/garcia13.pdf. Accessed 28 June 2017.

Grüne-Yanoff, T. (2012). Paradoxes of rational choice theory. In S. Roeser, R. Hillerbrand, P. Sandin, M. Peterson (Eds.), Handbook of risk theory: epistemology, decision theory, ethics, and social implications of risk, 499-516:London:Springer.

Henderson, J.M. , \& Quandt, R.E. (1980). Microeconomic theory: a mathematical approach. Singapore:McGraw - Hill.

Herfert, M. (2006).Nonparametric inference of utilites: entropy analysis with applications to consumer theory. Hamburg :diplom.de.

Holt, C. A. (1986). Preference reversal and the independence axiom. The American Economic Review, 76(3), 508-515.

Huygens, C. (1657). De ratiociniis in ludo aleae. (On reckoning at Games of Chance). London: T. Woodward.

Kahneman, D. , \& Tversky, A. (1979). Prospect theory: an analysis of decision under risk. Econometrica, 47(2), 263-292.

Kahneman, D., \& Tversky, A. (1984). Choices, values, and frames. American Psychologist, 39(4), 341-350. 
Kahneman, D. (2003). Maps of bounded rationality: psychology for behavioral economics.

The American Economic Review, 93(5), 1449-1475.

Karni, E. (2011). Continuity, completeness and the definition of weak preferences.

Mathematical Social Sciences, 62(2), 123-125.

Karni, E. (2007). Archimedean and continuity. Mathematical Social Sciences, 53(3), 332-334.

Keynes, J. M. (1921). A treatise on probability. London:Macmillan And Co.

Kreps, D. M. (1990). A course in microeconomic theory. USA:Harvester Wheatsheaf.

Levin, J. (2006). Choice under uncertainty. Resource document. Stanford University. https://web.stanford.edu/ jdlevin/Econ\%20202/Uncertainty.pdf. Accessed 28 June 2017.

Loomes, G. (1991). Evidence of a new violation of the independence axiom. Journal of Risk and Uncertainty, 4(1), 91-108 .

Loomes, G., Starmer, C., Sugden, R. (1991). Observing violations of transitivity by experimental methods. Econometrica, 59(2), 425-439 .

Machina, M. J. (1987). Choice under uncertainty: problems solved and unsolved. The Journal of Economic Perspectives, 1(1), 121-154.

Mas-Colell, A., Whinston, M. D. , Green, J. R. (1995). Microeconomic Theory. New York:Oxford University Press.

Menger, K. (1934). Das Unsicherheitsmoment in der Wertlehre. Nationaloeken, Journal of Economics, 5(4), 459 - 485.

Mobius, M. M. (2008). Motivation and decision theory. Resource document. Tsinghua University. http://iiis.tsinghua.edu.cn/ kenshin/gt/mlecture1.pdf. Accessed 28 June 2017.

Mongin, P. (1998). Expected utility theory. In J. B. Davis, D. W. Hands, Uskali Mäki (Eds.), The Handbook Of Economic Methodology, 171-178, UK:Edward Elgar Publishing.

Moschandreas, M. (2000). Business Economics. London:Thomson.

Mukhopadhyay, P. (2012). An introduction to the theory of probability. India:World Scientific.

Muñoz-Garcia, F. (2017). Advanced microeconomic theory: an intuitive approach with examples. Cambridge:MIT Press.

Ordoñez, G. (2007). Notes on decision theory. Resource document. University of

Pennsylvania.https://www.sas.upenn.edu/ ordonez/pdfs/ECON\%20201\%202007/EU. pdf. Accessed 28 June 2017.

Ore, O. ( 1953). Cardano the gambling scholar. New Jersey:Princeton University Press.

Pacioli, F. L. B. (1494). Summa de arithmetica, geometrica, proportioni et proportionalita. Venice. 
Peters, O. (2011). The time resolution of the St. Petersburg Paradox. Philosophical Transactions of the Royal Society A. Theme Issue 'Handling Uncertainty in Science, 120.

Pickover, C. A. (2009).The math book: from Pythagoras to the 57th dimension, 250 milestones in the history of mathematics. London: Sterling.

Salov, V. (2014). "The gibbon of math history". Who invented the St. Petersburg Paradox? Khinchin's resolution. arXiv:1403.3001v1 [math.HO], 1-17.

Schmeidler, D. (1971). A condition for the completeness of partial preference relations. Econometrica, 39(2), 403-04.

Schoemaker, P. J. H. (1982). The expected utility model: its variants, purposes, evidence and limitations. Journal of Economic Literature, 20(2), 529-563.

Shlesinger, M. F. (2012). Milestones in the history of probability. In L. Cohen, H. V. Poor, M. O. Scully (Eds.), Classical, semi-classical and quantum noise, 225-226, London: Springer.

Shon, J. (2008). More is better an investigation of monotonicity assumption in economics. Resource document. The University of Chicago. http://www.math.uchicago.edu/ may/VIGRE/VIGRE2008/REUPapers/Shon.pdf. Accessed 28 June 2017.

Slantchev, B. L. (2005). Game theory: preferences and expected utility. Resource document. University of California San Diego. http://slantchev.ucsd.edu/courses/gt/02preferences-expected-utility.pdf. Accessed 28 June 2017.

Stigler, S. M. (1999).Statistics on the table: the history of statistical concepts and methods. London: Harvard University Press.

Székely, G. J. , \& Richards, D. St. P. (2004). The St. Petersburg Paradox and the crash of high-tech stocks in 2000. The American Statistician, 58(3), 225-231.

Todhunter, I. (1865). A history of the mathematical theory of probability:from the time of Pascal to that of Laplace. London:MacMillan.

Tversky, A. (2004). Preference, belief, and similarity, selected writings. In E. Shafir (Ed.), A Bradford Book. London: The MIT Press.

Tversky, A. (1969). Intransitivity of preferences. Psychological Review, 76(1):31-48.

Tversky, A. ,\& Kahneman, D. (1981). The framing of decisions and the psychology of choice. Science, 211(4481), 453-458.

Tversky, A. , \& Kahneman, D. (1986). Rational choice and the framing of decisions, The Journal of Business, 59(4), Part 2: The Behavioral Foundations of Economic Theory, 251-278. 
Von Neumann, J., \& Morgenstern, O. (1944). Theory of games and economic behavior.

New Jersey:Princeton University.

Whitworth, W. A. (1901). Choice and chance. Cambridge: Deighton, Bell, \& Co. 